\title{
In vitro regulation of reactive oxygen species formation in red blood cells of homozygous sickle cell patients using Vitamin C
}

\section{[version 1; peer review: 2 approved with reservations]}

\author{
Ogechukwu Egini (D1), Edouard Guillaume1, Titilope Adeyemo², \\ Chiemeziem Nwanyanwu ${ }^{3}$, Fnu Shweta ${ }^{1}$, Eric Jaffe ${ }^{1}$ \\ ${ }^{1}$ Department of Internal Medicine, Interfaith Medical Center, Brooklyn, NY, 11213, USA \\ ${ }^{2}$ Department of Hematology and Blood Transfusion, Lagos University Teaching Hospital, Yaba, Nigeria \\ ${ }^{3}$ Department of Internal Medicine, Maimonides Medical Center, Brooklyn, NY, 11219, USA
}

\section{V1 First published: $25 \mathrm{Jul} 2017,6: 1212$ \\ https://doi.org/10.12688/f1000research.12126.1}

Latest published: $25 \mathrm{Jul}$ 2017, 6:1212

https://doi.org/10.12688/f1000research.12126.1

\begin{abstract}
Background: Sickle cell patients produce more reactive oxygen species (ROS) than healthy individuals, leading to increased cell membrane damage. Theoretically, reducing ROS formation would preserve red cell membranes of sickle cell patients. Vitamin C is a powerful anti-oxidant capable of inhibiting ROS formation in a variety of situations, by functioning as an electron donor to reduce molecular oxygen. This study aimed to determine whether Vitamin $\mathrm{C}$ reduced ROS formation in sickle red cells.

Methods: 27 homozygous (HbSS) patients were recruited from the outpatient clinics of Lagos University Teaching Hospital, Nigeria, and annex at the Sickle Cell Foundation, Lagos, Nigeria. Demographic information and EDTA patient blood samples were collected. The test group were red cells preincubated in 80uM and 100uM Vitamin C concentrations before stressing with tertbutylhydroperoxide. These were compared to stressed matched controls preincubated in phosphate buffered saline. Cell staining was done with CellRox Orange followed by flow cytometry to quantify ROS.

Results: ROS count for Vitamin C pre-treated red cells was significantly lower than matched controls $(p<0.001)$. Average ROS count for 80uM test samples was $27.5 / \mathrm{ul}$ ( $95 \% \mathrm{CI}, 17.5$ to 72.5 ) and for $100 u M$ 3.9/ul (95\% CI, 1.9 to 5.9 ). Male gender was significantly associated with elevated baseline ROS count ( $p=0.03)$.

Conclusion: Vitamin $\mathrm{C}$ reduced ROS formation in HbSS cells. Future studies should focus on a role for Vitamin C as a safe, cheap addition to maintenance therapy of sickle cell patients.
\end{abstract}

Keywords

Regulation, Reactive oxygen species, HbSS patients, Vitamin C

\section{Open Peer Review \\ Approval Status ? ? \\ 12

version $1 ?$ ? \\ 25 Jul 2017 \\ 1. Eitan Fibach (D), Hadassah University Hospital, Ein-Kerem, Jerusalem, Israel \\ 2. Edeghonghon Olayemi $[\mathrm{D}$, University of Ghana, Accra, Ghana}

Any reports and responses or comments on the article can be found at the end of the article. 
Corresponding author: Ogechukwu Egini (ogechukwu.egini@yahoo.com)

Author roles: Egini O: Conceptualization, Data Curation, Formal Analysis, Investigation, Methodology, Project Administration, Supervision, Validation, Visualization, Writing - Original Draft Preparation, Writing - Review \& Editing; Guillaume E: Supervision, Validation, Visualization, Writing - Review \& Editing; Adeyemo T: Investigation, Supervision, Writing - Review \& Editing; Nwanyanwu C: Formal Analysis, Validation, Writing - Review \& Editing; Shweta F: Validation, Writing - Review \& Editing; Jaffe E: Supervision, Writing Original Draft Preparation

Competing interests: No competing interests were disclosed.

Grant information: The author(s) declared that no grants were involved in supporting this work.

Copyright: ( $) 2017$ Egini $O$ et al. This is an open access article distributed under the terms of the Creative Commons Attribution License, which permits unrestricted use, distribution, and reproduction in any medium, provided the original work is properly cited. Data associated with the article are available under the terms of the Creative Commons Zero "No rights reserved" data waiver (CC0 1.0 Public domain dedication).

How to cite this article: Egini $O$, Guillaume $E$, Adeyemo $T$ et al. In vitro regulation of reactive oxygen species formation in red blood cells of homozygous sickle cell patients using Vitamin C [version 1; peer review: 2 approved with reservations] F1000Research 2017, 6:1212 https://doi.org/10.12688/f1000research.12126.1

First published: $25 \mathrm{Jul}$ 2017, 6:1212 https://doi.org/10.12688/f1000research.12126.1 


\section{Introduction}

Sickle cell anemia is a single-nucleotide polymorphism due to substitution of glutamic acid by valine at position 6 of the B-globin chain ${ }^{1}$. In the homozygous (HbSS) state, this occurs on both B-globin chains leading to severe disease. Paulson et al. demonstrated a direct quantitative effect of the sickle gene pair on sufferers ${ }^{2}$. The $\mathrm{HbS}$ molecule polymerizes easily under stress conditions with formation of insoluble polymers, which distort red cell shape, leading to membrane damage and eventual red cell breakdown ${ }^{1}$. Conditions implicated in sickle red cell stress include hypoxia, infections and dehydration. These cause formation of reactive oxygen species (ROS), which oxidatively damage cell membranes ${ }^{3}$. ROS has a multiplier effect leading to more ROS generation, establishing a positive feedback system, the end-result of which is damage to red cell membranes ${ }^{4}$. Sickle red cells produce greater amounts of ROS than normal cells and are also more susceptible to oxidation ${ }^{5}$.

ROS formation is maximal during the reperfusion state when there is increased formation of methemoglobin and superoxide ion due to electron transfers that occur between the heme iron and oxygen ${ }^{6}$. Comparatively, $\mathrm{HbS}$ molecules auto-oxidize more than the $\mathrm{HbA}$ molecules and also have a poor mechanism to clear generated superoxide ion ${ }^{7}$. Consequently, the lifespan of the sickle red cell is about $1 / 5^{\text {th }}$ that of the normal red cell ${ }^{8}$.

Theoretically, reducing the ROS formation would ameliorate $\mathrm{HbS}$ molecule and lipid membrane polymerization and improve red cell life span. In a flow cytomeric comparison of ROS production in normal vs thalassaemic red cells, significantly higher ROS generation in thalassaemic red cells was noted ${ }^{5}$. In addition, pretreatment of the red cells with $\mathrm{N}$-acetyl-L-cysteine ameliorated the generation of ROS in both the normal and thalassaemic cells after the cells were stressed with 2',7'-dichlorofluorescein diacetate, a potent inducer of ROS formation. Furthermore, Furman et al. found that sickle red cell pretreatment with Ginkgo biloba extract prior to cell stressing also ameliorated ROS, and reduced membrane polymerization and formation of methemoglobin ${ }^{9}$.

Vitamin $\mathrm{C}$ is a powerful anti-oxidant, working as an electron donor capable of reducing molecular oxygen ${ }^{10,11}$, making it important in a variety of physiological processes and reactions in the human body, including, fatty acid transport ${ }^{12}$, synthesis of collagen $^{13}$, prostaglandin metabolism ${ }^{14}$ and neurotransmitter synthesis $^{15}$. Vitamin $\mathrm{C}$ is almost completely absorbed in the distal small intestine via energy-dependent processes ${ }^{16}$ and exhibits a steady-state concentration at oral doses of $200-400 \mathrm{mg} /$ day, corresponding to plasma concentrations between $60-100 \mathrm{umol} / \mathrm{L}^{17}$. Vitamin $\mathrm{C}$ is cheap, well-studied and readily available, making it attractive to study as a regulator of ROS formation in sickle red cells.

\section{Statement of the problem}

Nigeria has the highest number of people with sickle cell disease (SCD) in the world, with an estimated 91,000 babies born with the condition yearly ${ }^{18}$. This number is expected to grow. This means that Nigeria and other countries with a high disease burden will continue to require research to improve policies for prevention and management of sickle cell patients. Catastrophic financial burden has occurred in families of sickle cell patients evaluated in a study in Ekiti State, Nigeria ${ }^{19}$. Many of these families spent over $10 \%$ of family income to cover hospital admissions of an SCD patient and greater than $90 \%$ of these families had no health insurance and had to borrow to meet their financial needs. This study investigated a possible role for Vitamin C, a cheap drug, in reducing ROS formation in sickle cell patients.

\section{Methods}

Subject recruitment and collection of samples

Institutional approval was given by the Lagos University Teaching Hospital Health Research Ethics Committee (Assigned number: ADM/DCST/HREC/APP/1533). $27 \mathrm{HbSS}$ patients were recruited from the Sickle Cell Clinic of Lagos University Teaching Hospital (LUTH) and LUTH clinic annex at Sickle Cell Foundation of Nigeria, Lagos Office between May 22-25, 2017. These patients were known HbSS patients documented on file and previously confirmed by hemoglobin electrophoresis. Every $3^{\text {rd }}$ HbSS patient who presented in the clinic and met the inclusion criteria was enrolled in the study after written informed consent was obtained in accordance with the Declaration of Helsinki. Afterwards, a screening questionnaire was applied to obtain each candidate's demographics followed by weight and height measurements. Four volunteers declined height and weight assessment. $4 \mathrm{mls}$ of fresh blood was then drawn from the antecubital vein of each enrolled candidate into EDTA tubes. All samples were analyzed within 4 hours of collection.

Inclusion criteria. Patients of all ages who did not receive blood transfusion within 3 months and had not taken Vitamin C or multivitamin supplements within 3 months of the study were recruited. Patients taking hydroxyurea were included if they had been on a stable dose for at least 3 months.

Exclusion criteria. Blood transfusion within 3 months of study; acutely-ill patients; use of Vitamin $\mathrm{C}$ or multivitamin supplements within 3 months.

\section{Materials and reagents}

Gibco Phosphate-buffered saline (PBS; catalog number 20012043; Life Technologies, Grand Island, New York). CellRox Orange Flow Cytometry Assay kit (catalog number: C10493; Life Technologies). The kit includes the fluorophore, CellRox Orange reagent; $\mathrm{N}$-acetyl cysteine (NAC; an antioxidant) and tert-butyl hydroperoxide solution (TBHP; to induce ROS). CellRox Orange reagent localizes to the cell cytoplasm and has absorption/emission maxima of 545/565 nm respectively ${ }^{20}$. L-Ascorbic acid powder (CSPC Weisheng Pharmaceutical, China); a 200uM solution of Vitamin C was prepared in cold PBS and protected from light.

\section{Sample preparation}

Sample preparation and analysis were done at the Nigerian Institute of Medical Research - Human Virology Lab (NIMR-HVL), an ISO-certified lab in Yaba, Lagos. Pre-wash red cell counts for all samples were obtained from the hematology analyzer before centrifugation at 500xg for 10 minutes and supernatant removal. Cells were washed thrice in cold PBS and finally re-suspended in $5 \mathrm{mls}$ 
of PBS followed by determination of post-wash red cell count. This step was an adaptation of a previous process ${ }^{21}$.

\section{Cell treatment}

The protocol for this step was adapted from Life Technologies standardized protocol ${ }^{20}$. For each sample, volume corresponding to $5 \times 10^{5}$ cells was pipetted into four different micro-centrifuge tubes. One was immediately incubated with CellRox orange stain at a final concentration of 500nM and ROS quantified on the Partec Cyflow Counter Version 2.4 to determine basal ROS present per sample. Another tube was incubated with PBS and then stressed at final concentration of 200uM TBHP to serve as control. Two other tubes were pre-treated with $80 \mathrm{uM}$ and $100 \mathrm{uM}$ concentrations of Vitamin $\mathrm{C}$ respectively, before stressing with 200uM TBHP to represent the test samples. In a supplemental study, nine samples were non-randomly selected and incubated with $200 \mathrm{uM}$ NAC followed by TBHP stressing. Incubation time per added reagent was 30 minutes.

\section{Cell staining and flow cytometry}

CellRox Orange was prepared with DMSO and then added to all the samples described above at a final concentration of 500nM. After 30 minutes of incubation, $800 \mathrm{uL}$ of the solution was transferred into Rohren tubes for immediate analysis on the flow cytometer. A total of $5 \times 10^{5}$ cells were analysed and pulsed gating was used to exclude doublets.

\section{Statistical analysis}

The primary outcome measure was a comparison of the quantity of ROS formed following stressing of test vs control cells. Secondary analyses evaluated the relationship between gender, age, BMI and hydroxyurea use on basal ROS in sickle red cells. Microsoft Excel Version 14 was used for analysis. Analysis of variance (ANOVA) was used for statistical comparisons (significance defined by $P$ values $\leq 0.05)$.

\section{Results}

Characteristics of the participants

27 participants were recruited into the study. The sample was equally distributed between males and females (Table 1). Blood transfusion rate in this population was lower than among Congolese sickle cell patients ${ }^{22}$, but higher than for U.S Medicaid patients seen between 2007-2012 23 . Hydroxyurea utilization was higher than among Florida Medicaid patients ${ }^{24}$ and improved over a previous report from a major Nigerian Teaching Hospital ${ }^{25}$.

\section{Red cell count}

Average pre-wash red cell count was $2.89 \times 10^{12} / \mathrm{L}$. The average male red cell count was higher than females (Table 2). Post-wash red cell count was calculated after final cell suspension. Volume equivalent of $5 \times 10^{5}$ red cells was calculated from the post-wash red cell count (Table 2).

\section{Table 1. Baseline characteristics of study participants.}

\begin{tabular}{|c|c|c|}
\hline Characteristic & $\mathbf{N}$ & $\%$ \\
\hline \multicolumn{3}{|l|}{ Age } \\
\hline$<10$ & 2 & 7.4 \\
\hline 10-19 & 3 & 11.1 \\
\hline 20-29 & 15 & 55.6 \\
\hline $30-39$ & 4 & 14.8 \\
\hline $40-49$ & 3 & 11.1 \\
\hline \multicolumn{3}{|l|}{ Gender } \\
\hline Male & 14 & 51.9 \\
\hline Female & 13 & 48.1 \\
\hline \multicolumn{3}{|l|}{ BMI } \\
\hline Underweight (<18.5) & 10 & 33.3 \\
\hline Normal (18.5-24.9) & 11 & 40.7 \\
\hline Overweight ( $\geq 25$ ) & 2 & 7.4 \\
\hline Data missing & 4 & 18.5 \\
\hline \multicolumn{3}{|l|}{ Employment status } \\
\hline Employed & 6 & 22.2 \\
\hline Unemployed & 21 & 77.8 \\
\hline \multicolumn{3}{|l|}{ History of blood transfusion } \\
\hline Transfused $^{\star}$ & 13 & 48.1 \\
\hline Never transfused & 14 & 51.9 \\
\hline \multicolumn{3}{|l|}{ Hydroxyurea status } \\
\hline Currently on hydroxyurea & 9 & 33.3 \\
\hline Not on hydroxyurea & 18 & 66.7 \\
\hline
\end{tabular}

\section{Relationship between baseline ROS count and patient characteristics}

Baseline ROS count (BRC) refers to number of ROS per ul before any red cell intervention. Average total BRC was 441.9/ul (Table 2). When BRC was matched in terms of gender, men were found to have a significantly higher count than women, with average ROS count of 583.1/ul (95\% CI, 373.1 to 793.1; p-value $=0.03$; Table 3). Average BRC for those $\geq 20$ years was higher than those $<20$ years; those with $\mathrm{BMI} \geq 18.5$ had higher average ROS than those $<18.5$; and those on hydroxyurea also had higher average basal ROS than those not taking hydroxyurea. 
Table 2. Baseline characteristics, red cell count and reactive oxygen species formation per sample for each reaction.

\begin{tabular}{|c|c|c|c|c|c|c|c|c|c|c|}
\hline \multirow[t]{2}{*}{ Samples } & \multirow[t]{2}{*}{ Gender } & \multirow[t]{2}{*}{ Age } & \multirow[t]{2}{*}{ BMI } & \multirow[t]{2}{*}{ HS } & \multicolumn{2}{|c|}{$\begin{array}{l}\text { Red cell count } \\
\quad\left(\times 10^{12} / \mathrm{L}\right)\end{array}$} & \multicolumn{4}{|c|}{ ROS count per ul } \\
\hline & & & & & Prewash & Postwash & Baseline & Control & 80uM Vit. C & 100uM Vit. C \\
\hline 1 & M & 0 & $N / D$ & 0 & 2.97 & 2.05 & 348 & 670 & 2 & 2 \\
\hline 2 & M & 0 & 1 & 0 & 2.80 & 1.92 & 668 & 793 & 1 & 1 \\
\hline 3 & M & 0 & 0 & 0 & 2.90 & 1.96 & 339 & 1342 & 3 & 1 \\
\hline 4 & M & 1 & 0 & 1 & 2.64 & 1.81 & 318 & 1768 & 3 & 3 \\
\hline 5 & $\mathrm{~F}$ & 0 & 1 & 0 & 3.12 & 2.19 & 401 & 1360 & 2 & 2 \\
\hline 6 & $\mathrm{~F}$ & 0 & 1 & 0 & 2.46 & 1.72 & 359 & 1171 & 627 & 3 \\
\hline 7 & M & 0 & 0 & 0 & 3.19 & 2.04 & 183 & 339 & 4 & 3 \\
\hline 8 & $\mathrm{~F}$ & 0 & 1 & 0 & 2.43 & 1.72 & 205 & 470 & 4 & 2 \\
\hline 9 & $M$ & 1 & N/D & 1 & 2.81 & 1.78 & 441 & 561 & 1 & 1 \\
\hline 10 & $\mathrm{~F}$ & 0 & 1 & 0 & 3.11 & 1.84 & 257 & 729 & 6 & 1 \\
\hline 11 & $\mathrm{~F}$ & 1 & $\mathrm{~N} / \mathrm{D}$ & 1 & 2.38 & 1.63 & 330 & 562 & 18 & 0 \\
\hline 12 & $F$ & 0 & 0 & 0 & 2.78 & 1.97 & 272 & 907 & 3 & 2 \\
\hline 13 & M & 0 & 1 & 0 & 3.66 & 2.61 & 197 & 678 & 5 & 3 \\
\hline 14 & $F$ & 1 & $\mathrm{~N} / \mathrm{D}$ & 1 & 2.85 & 1.87 & 305 & 844 & 2 & 1 \\
\hline 15 & $\mathrm{~F}$ & 0 & 0 & 0 & 2.69 & 1.74 & 192 & 626 & 2 & 3 \\
\hline 16 & $F$ & 0 & 1 & 0 & 3.04 & 1.49 & 332 & 1373 & 5 & 2 \\
\hline 17 & $\mathrm{M}$ & 0 & 1 & 0 & 3.01 & 1.88 & 169 & 714 & 3 & 3 \\
\hline 18 & $F$ & 1 & 1 & 1 & 1.88 & 0.78 & 47 & 186 & 5 & 5 \\
\hline 19 & $\mathrm{~F}$ & 0 & 0 & 0 & 2.76 & 1.69 & 82 & 363 & 3 & 3 \\
\hline 20 & $\mathrm{~F}$ & 0 & 0 & 0 & 2.81 & 1.12 & 95 & 250 & 3 & 28 \\
\hline 21 & $M$ & 0 & 0 & 0 & 5.62 & 2.37 & 464 & 578 & 5 & 4 \\
\hline 22 & $M$ & 0 & 1 & 0 & 2.62 & 1.40 & 735 & 1747 & 15 & 6 \\
\hline 23 & $\mathrm{M}$ & 1 & 0 & 1 & 1.93 & 1.35 & 1539 & 1322 & 5 & 3 \\
\hline 24 & $M$ & 0 & 1 & 0 & 2.52 & 1.39 & 1163 & 1473 & 4 & 11 \\
\hline 25 & $M$ & 1 & 0 & 1 & 2.67 & 1.52 & 863 & 1345 & 5 & 4 \\
\hline 26 & $M$ & 1 & 1 & 1 & 3.17 & 1.69 & 737 & 836 & 3 & 4 \\
\hline 27 & $F$ & 1 & 1 & 1 & 3.45 & 2.14 & 890 & 1029 & 3 & 4 \\
\hline \multicolumn{5}{|l|}{ Average } & 2.89 & 1.76 & 441.9 & 890.2 & 27.5 & 3.9 \\
\hline
\end{tabular}

M - male; F - female; HS - Hydroxyurea Status; N/D - not determined; Vit.C - Vitamin C. Scoring system - Age: 0 means <20 years and 1 means $\geq 20$ years; $\mathrm{BMI}$ : 0 means $<18.5$ and 1 means $\geq 18.5$; hydroxyurea status: 0 refers to those not taking and 1 to those taking hydroxyurea.

Baseline ROS prediction score

A score of 1 each was given to the male subjects, subjects on hydroxyurea at time of recruitment, age $\geq 20$ years and for BMI $\geq$ 18.5. A score of 0 was applied in each case for women, those not on hydroxyurea, aged $<20$ years and BMI $<18.5$ (Table 2). Average $\mathrm{BRC}$ for subjects with scores $\geq 3$ were higher than those with scores 2 , though not significant ( $\mathrm{p}$-value $=0.11$ ). When each score cohort was matched in terms of gender, the average ROS production for men remained higher than for women without statistical signifance (Table 3).
Vitamin $\mathrm{C}$ regulation of ROS formation in stressed red cells ROS count after TBHP stressing of test and matched controls were compared for each sample (Figure 1). The controls had a higher ROS count than test cells. As shown in Figure 2, at both concentrations of Vitamin C, there were significantly less ROS formation than controls (p-value $<0.001$ ). Average ROS count for $80 \mathrm{uM}$ test samples was $27.5 /$ ul (95\% CI, 17.5 to 72.5 ) and for 100uM test group, it was 3.9/ul (95\% CI, 1.9 to 5.9). No statistical difference existed between Vitamin C pretreatment at $80 \mathrm{uM}$ and at $100 \mathrm{uM}$ $(\mathrm{p}$-value $=0.31)$. 
Table 3. Average total and gender-matched baseline ROS count.

\begin{tabular}{|l|l|l|l|l|l|l|}
\hline Gender & $\begin{array}{l}\text { Average total } \\
\text { ROS per ul }\end{array}$ & P-value & $\begin{array}{l}\text { Average total } \\
\text { ROS per ul for } \\
\text { score } \geq \mathbf{3}\end{array}$ & P-value & $\begin{array}{l}\text { Average total } \\
\text { ROS per ul for } \\
\text { score 2 }\end{array}$ & P-value \\
\hline Male & $\begin{array}{l}583.1(95 \% \mathrm{Cl}, \\
\text { 373.1 to } 793.1)\end{array}$ & 0.03 & 719.0 & 0.55 & 463.4 & 0.37 \\
\hline Female & $\begin{array}{l}289.8(95 \% \mathrm{Cl} \\
169.8 \text { to } 409.8)\end{array}$ & 468.5 & & 305.5 & \\
\hline
\end{tabular}

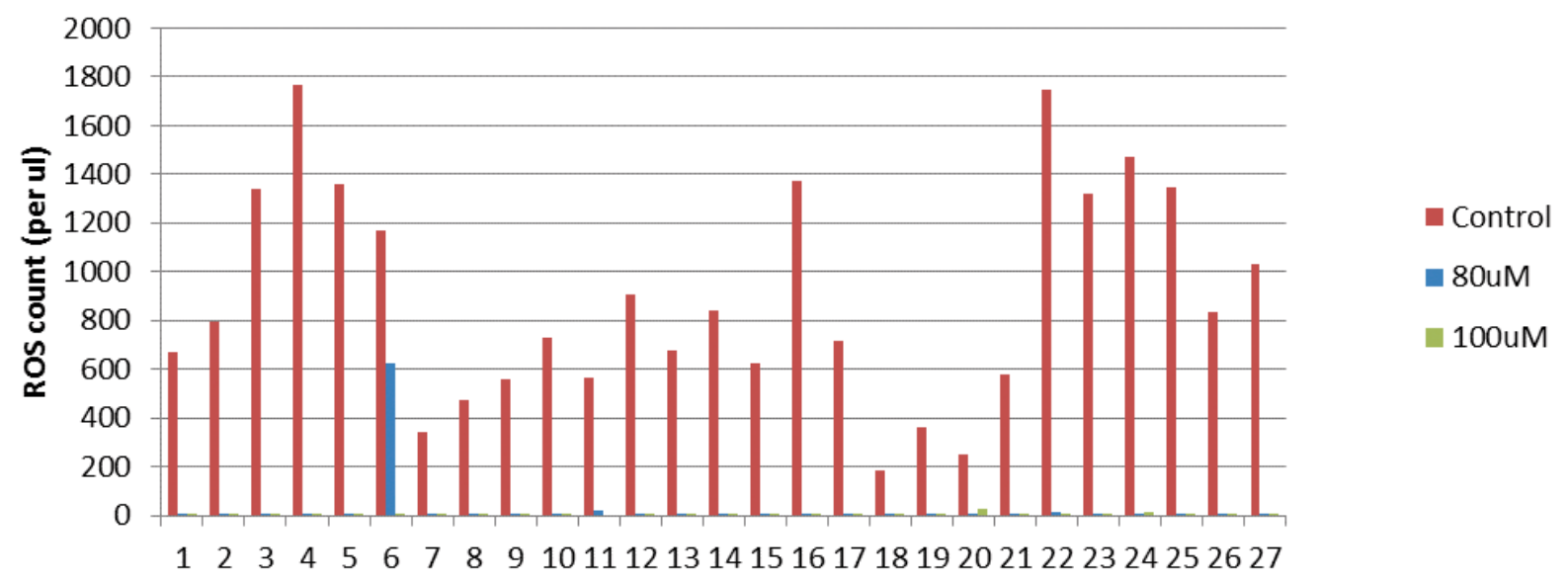

Figure 1. ROS count per sample matched for control and at $80 \mathrm{uM}$ and $100 \mathrm{uM}$ Vitamin $\mathrm{C}$ pretreatment.

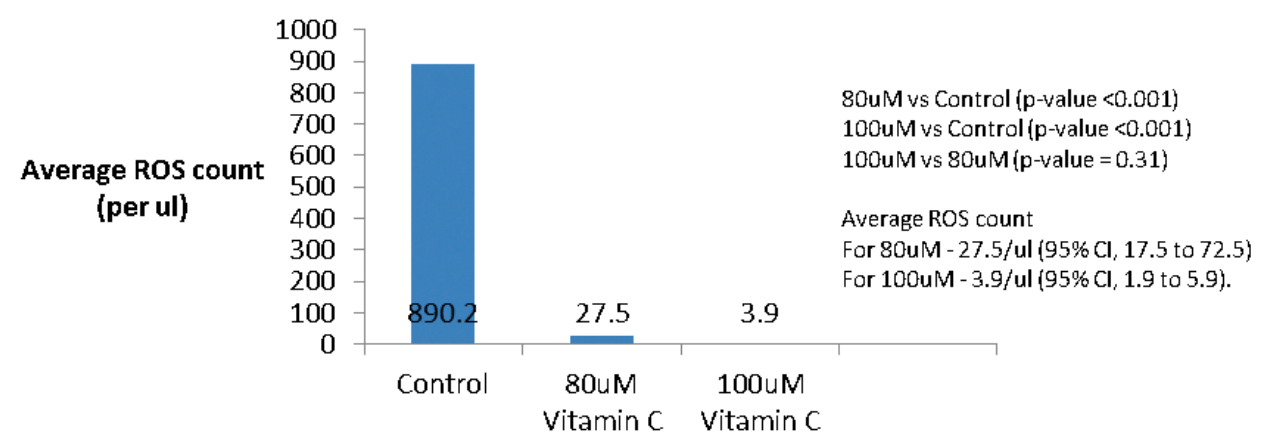

Figure 2. Average ROS count for control and following 80uM and 100uM Vitamin C pretreatment.

NAC regulation of ROS formation - a supplemental analysis

We compared a subset of controls with NAC-pretreated cells. Samples $1-9$ were pre-treated with 200uM NAC and the results compared with matched controls pretreated with PBS (Table 4 and Figure 3). NAC at 200uM final concentration reduced ROS formation compared to control. However, no statistical significance was noted $(\mathrm{p}$-value $=0.12)$.
Dataset 1. Baseline characteristics, measured heights, weights and calculated BMI, red cell count and reactive oxygen species formation per sample

http://dx.doi.org/10.5256/f1000research.12126.d169449

$\mathrm{M}$ - male; F - female; HS - Hydroxyurea Status; Y/N - Yes/No answers for hydroxyurea use and blood transfusion history; Vit.C - Vitamin C; N/D - not determined. 


\section{Table 4. Sample cohort comparing positive control with 200um NAC.}

\begin{tabular}{|l|l|l|}
\hline Samples & $\begin{array}{l}\text { Control } \\
\text { (per ul) }\end{array}$ & $\begin{array}{l}\text { NAC-treated } \\
\text { (per ul) }\end{array}$ \\
\hline 1 & 670 & 816 \\
\hline 2 & 793 & 734 \\
\hline 3 & 1342 & 590 \\
\hline 4 & 1768 & 571 \\
\hline 5 & 1360 & 329 \\
\hline 6 & 1171 & 1221 \\
\hline 7 & 339 & 633 \\
\hline 8 & 470 & 581 \\
\hline 9 & 561 & 263 \\
\hline Average & 941.6 & 637.6 \\
\hline P-value $=$ & 0.12 & \\
\hline
\end{tabular}

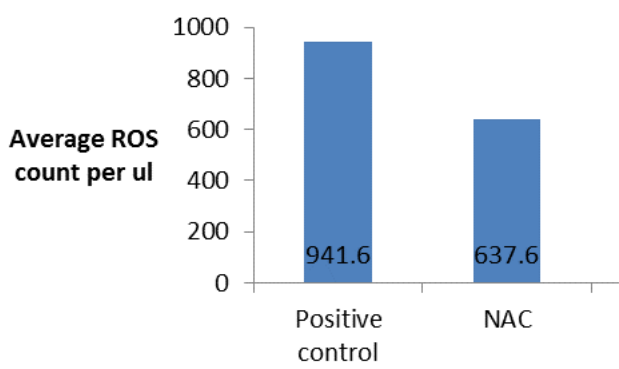

Figure 3. Average ROS count for control and following 200uM NAC pretreatment.

\section{Discussion \\ Individual characteristics and baseline reactive oxygen species count}

Individually, age $\geq 20$ years, $\mathrm{BMI} \geq 18.5$, hydroxyurea use and the male gender appear to be associated with increased baseline ROS count (BRC). In normal subjects, a statistically significant correlation was described by Kukovetz et al. between increasing age and generation of $\operatorname{ROS}^{26}$. However, even though our study did not show a statistical significance between increasing age and increased BRC, an appropriate path would be to investigate this relationship further with larger patient cohorts. Furthermore, this study has revealed an association between BMI $\geq 18.5$ and increased BRC. Previously, a relationship between increasing obesity and generation of serum ROS Japanese students was noted ${ }^{27}$, while increased ROS production has been described in obese diabetics, particularly with abdominal obesity ${ }^{28}$. We also found that patients on hydroxyurea had a higher average BRC than those not taking hydroxyurea. It has been shown that hydroxyurea mediated $E$. coli cell death by inducing envelope ROS formation leads to membrane damage and cell death ${ }^{29,30}$. Elevated ROS formation has also been seen in hydroxyurea-treated yeast cell cytoplasm ${ }^{31}$. Hydroxyurea inhibits ribonucleotide reductase leading to a replication fork arrest ${ }^{32}$ and accumulation of ROS. Male gender is an independent factor statistically associated with increased BRC $(\mathrm{p}<0.05)$ in this study. Previous studies have shown that men have increased oxidative stress levels, more biomarkers of stress, elevated ROS production and lower antioxidant levels ${ }^{33-36}$. Among sickle cell patients in a Camerounian Hospital, women had a greater total anti-oxidant capacity compared with males ${ }^{37}$. Our data showed that, on average, men aged $\geq 20$ years whose BMI were $\geq 18.5$ and who were also on hydroxyurea produced more ROS. This is equivalent to Score 3 on the baseline ROS score described in the Results section. This group might be a target for an ROS-reducing agent. Further studies are required here.

Vitamin $\mathrm{C}$ regulation of ROS formation in stressed cells A significant reduction in ROS formation for all test samples pretreated with $80 \mathrm{uM}$ and $100 \mathrm{uM}$ concentrations of Vitamin $\mathrm{C}$ prior to tert-butyl hydroperoxide stressing vs matched controls ( $\mathrm{P}$-values $<0.05$ ) was noted. It is evident that Vitamin $\mathrm{C}$ inhibited formation of ROS formation in test cells and may have served to protect the red cell membrane from damage. Guaiquil et al. found that increased sensitivity of glutathione-depleted human myeloid cells to membrane damage was significantly reversed by preloading with Vitamin $\mathrm{C}^{38}$. As noted earlier, there is a reduction in ROS formation in murine models with pulmonary contusion treated with Vitamin $\mathrm{C}^{11}$.This finding is significant because if we can reduce ROS formation in sickle cell patients by simply administering Vitamin C, we would theoretically reduce cell injury and improve disease-free intervals for patients. Our study did not find a significant difference in ROS formation between cell cohorts pretreated at $80 \mathrm{uM}$ vs $100 \mathrm{uM}$ concentrations of Vitamin C. One sample pretreated with $80 \mathrm{uM}$ Vitamin $\mathrm{C}$ did not show as much reduction in ROS in the degrees seen with other samples (Figure 1). This effect was not noted at incubation with $100 \mathrm{uM}$ Vitamin C. This might be due to individual variation in response rates at $80 \mathrm{uM}$ concentration. It is possible that extending Vitamin $\mathrm{C}$ incubation time beyond 30 minutes might have yielded larger changes.

Rate of cell lysis between treated vs control was not compared in this study. It will be interesting to see if the treated cells were more resistant to lysis than matched controls. Additionally, controlled studies to examine the effect on basal ROS formation of administering Vitamin $\mathrm{C}$ to sickle cell patient cohorts over time would be appropriate.

\section{Supplemental information}

$\mathrm{N}$-acetylcysteine did not significantly reduce ROS. When compared to Vitamin $\mathrm{C}$, there was a significant difference in efficacy, with Vitamin $\mathrm{C}$ showing superiority over NAC. It may help to consider other concentrations of NAC in future experiments. 


\section{Conclusion}

Vitamin C significantly decreased ROS formation in stressed red cells of sickle cell patients. Future studies are required to evaluate the effect of Vitamin $\mathrm{C}$ administration on sickle cell patients.

\section{Data availability}

Dataset 1. Baseline characteristics, measured heights, weights and calculated BMI, red cell count and reactive oxygen species formation per sample. M - male; F - female; HS - Hydroxyurea Status; Y/N - Yes/No answers for hydroxyurea use and blood transfusion history; Vit.C - Vitamin C; N/D - not determined. doi, 10.5256/f1000research.12126.d169449 ${ }^{39}$

Competing interests

No competing interests were disclosed.

\section{Grant information}

The author(s) declared that no grants were involved in supporting this work.

\section{Acknowledgements}

We thank the staff of the Nigerian Medical Research Institute, especially the Director-General, Prof. Salako; Deputy Director of Research, Dr. Audu and Mr. Jamda for providing technical support for our project. We are grateful to Dr. Kalejaiye, Consultant Hematologist at LUTH and Dr. Fezie Nnaji, Primary Care Physician at Simeon Hospital, Lagos who helped recruit sickle cell patients. Valentine Egini and Colins Nwosu supported logistics and transport. Stephanie Egini typeset the manuscript and Dr. Abraham Bezuneh provided valuable advice. Finally, we are very grateful to Dr. Mark Adler, Internal Medicine Program Director, Interfaith Medical Center for manuscript review.
1. Ingram VM: Abnormal human haemoglobins. III. The chemical difference between normal and sickle cell haemoglobins. Biochim Biophys Acta. 1959; 36: 402-411. PubMed Abstract | Publisher Full Text

2. Pauling $\mathrm{L}$, Itano $\mathrm{HA}$, Singer $\mathrm{S}$, et al: Sickle cell anemia a molecular disease. Science. 1949; 110(2865): 543-548. PubMed Abstract | Publisher Full Text

3. Ilesanmi OO: Pathological basis of symptoms and crises in sickle cell disorder: implications for counseling and psychotherapy. Hematol Rep. 2010; 2(1): e2. PubMed Abstract | Publisher Full Text | Free Full Text

4. Zorov DB, Juhaszova M, Sollott SJ: Mitochondrial reactive oxygen species (ROS) and ROS-induced ROS release. Physiol Rev. 2014; 94(3): 909-950. PubMed Abstract | Publisher Full Text | Free Full Text

5. Amer J, Goldfarb A, Fibach E: Flow cytometric measurement of reactive oxygen species production by normal and thalassaemic red blood cells. Eur J Haematol. 2003; 70(2): 84-90. PubMed Abstract | Publisher Full Text

6. Gu J, Chang TM: Extraction of erythrocyte enzymes for the preparation of polyhemoglobin-catalase-superoxide dismutase. Artif Cells Blood Substit Immobil Biotechnol. 2009; 37(2): 69-77. PubMed Abstract | Publisher Full Text | Free Full Text

7. Hebbel RP, Morgan WT, Eaton JW, et al:: Accelerated autoxidation and heme loss due to instability of sickle hemoglobin. Proc Natl Acad Sci U S A. 1988; 85(1): 237-241.

PubMed Abstract | Publisher Full Text | Free Full Text

8. McCurdy PR, Sherman AS: Irreversibly sickled cells and red cell survival in sickle cell anemia: a study with both DF32P and 51CR. Am J Med. 1978; 64(2): 253-258.

PubMed Abstract | Publisher Full Text

9. Furman $\mathrm{AE}$, Henneberg R, Hermann PB, et al:: Ginkgo biloba extract (EGb 761) attenuates oxidative stress induction in erythrocytes of sickle cell disease patients. Braz J Pharm Sci. 2012; 48(4): 659-665. Publisher Full Text

10. Ramanathan K, Balakumar BS, Panneerselvam C: Effects of ascorbic acid and alpha-tocopherol on arsenic-induced oxidative stress. Hum Exp Toxicol. 2002; 21(12): 675-680

PubMed Abstract | Publisher Full Text

11. Sirmali $\mathrm{R}$, Geniş $\mathrm{Z}$, Sirmali $\mathrm{M}$, et al:: Vitamin $\mathrm{C}$ as an antioxidant: evaluation of its role on pulmonary contusion experimental model. Turk J Med Sci. 2014; 44(6): 905-913.

PubMed Abstract | Publisher Full Text

12. Rebouche $\mathrm{CJ}$ : Renal handling of carnitine in experimental vitamin $\mathbf{C}$ deficiency. 1995; 44(12): 1639-43. PubMed Abstract | Publisher Full Text

13. Ronchetti IP, Quaglino D Jr, Bergamini G: Ascorbic acid and connective tissue Subcell Biochem. Harris JR (Ed), Plenum Press, New York. 1996; 25: 249-64. PubMed Abstract | Publisher Full Text
14. Horrobin DF: Ascorbic acid and prostaglandin synthesis. Subcell Biochem Harris JR (Ed), Plenum Press, New York. 1996; 25: 109-115. PubMed Abstract | Publisher Full Text

15. Katsuki $\mathrm{H}$ : Vitamin $\mathrm{C}$ and nervous tissue. In vivo and in vitro aspects. Subcell Biochem. Harris JR (Ed), Plenum Press, New York. 1996; 25: 293-311. PubMed Abstract | Publisher Full Text

16. Mellors AJ, Nahrwold DL, Rose RC: Ascorbic acid flux across mucosal border of guinea pig and human ileum. Am J Physiol. 1977; 233(5): E374-E379. PubMed Abstract

17. Levine $\mathrm{M}$, Conry-Cantilena $\mathrm{C}$, Wang $\mathrm{Y}$, et al.: Vitamin $\mathrm{C}$ pharmacokinetics in healthy volunteers: evidence for a recommended dietary allowance. Proc Nat Acad Sci U S A. 1996; 93(8): 3704-3709. PubMed Abstract | Publisher Full Text | Free Full Text

18. Piel FB, Hay SI, Gupta S, et al.: Global burden of sickle cell anaemia in children under five, 2010-2050: modelling based on demographics, excess mortality, and interventions. PLoS Med. 2013; 10(7): e1001484. PubMed Abstract | Publisher Full Text | Free Full Text

19. Olatunya OS, Ogundare EO, Fadare JO, et al:: The financial burden of sickle cell disease on households in Ekiti, Southwest Nigeria. Clinicoecon Outcomes Res. 2015; 7: 545-53.

PubMed Abstract | Publisher Full Text | Free Full Text

20. Thermo Fisher Scientific: CellRox ${ }^{\mathrm{TM}}$ Orange Reagent for oxidative stress detection. 2017. Reference Source

21. Hanson MS, Stephenson AH, Bowles EA, et al:: Phosphodiesterase 3 is present in rabbit and human erythrocytes and its inhibition potentiates iloprostinduced increases in cAMP. Am J Physiol Heart Circ Physiol. 2008; 295(2): H786-93. PubMed Abstract | Publisher Full Text | Free Full Text

22. Tshilolo LM, Mukendi RK, Wembonyama SO: Blood transfusion rate in Congolese patients with sickle cell anemia. Indian J Pediat. 2007; 74(8): 735-738. PubMed Abstract | Publisher Full Text

23. Nouraie M, Gordeuk VR: Blood transfusion and 30-day readmission rate in adult patients hospitalized with sickle cell disease crisis. Transfusion. 2015; 55(10): 2331-2338.

PubMed Abstract | Publisher Full Text | Free Full Text

24. Ritho J, Liu H, Hartzema AG, et al.: Hydroxyurea use in patients with sickle cell disease in a Medicaid population. Am J Hematol. 2011; 86(10): 888-890. PubMed Abstract | Publisher Full Text

25. Aliyu ZY, Babadoko A, Mamman A: Hydroxyurea Utilization in Nigeria, a Lesson in Public Health. Blood. 2007; 110(11): 80. Reference Source

26. Kukovetz EM, Bratschitsch G, Hofer HP, et al: Influence of age on the release of reactive oxygen species by phagocytes as measured by a whole blood chemiluminescence assay. Free Radic Biol Med. 1997; 22(3): 433-438. PubMed Abstract | Publisher Full Text 
Kogawa T, Kashiwakura I: Relationship between obesity and serum reactive oxygen metabolites in adolescents. Environ Health Prev Med. 2013; 18(6): 451-457.

PubMed Abstract | Publisher Full Text | Free Full Text

28. Hirao K, Maruyama T, Ohno $\mathrm{Y}$, et al.: Association of increased reactive oxygen species production with abdominal obesity in type 2 diabetes. Obes Res Clin Pract. 2010; 4(2): e83-e90.

PubMed Abstract | Publisher Full Text

29. Davies BW, Kohanski MA, Simmons LA, et al:: Hydroxyurea induces hydroxyl radical-mediated cell death in Escherichia coli. Mol Cell. 2009; 36(5): 845-860. PubMed Abstract | Publisher Full Text | Free Full Text

30. Nakayashiki T, Mori H: Genome-wide screening with hydroxyurea reveals a link between nonessential ribosomal proteins and reactive oxygen species production. J Bacteriol. 2013; 195(6): 1226-1235.

PubMed Abstract | Publisher Full Text | Free Full Text

31. Huang ME, Facca C, Fatmi Z, et al.: DNA replication inhibitor hydroxyurea alters Fe-S centers by producing reactive oxygen species in vivo. Sci Rep. 2016; 6 : 29361.

PubMed Abstract | Publisher Full Text | Free Full Text

32. Rosenkranz HS, Winshell EB, Mednis A, et al:: Studies with hydroxyurea. VII. Hydroxyurea and the synthesis of functional proteins. J Bacteriol. 1967; 94(4): 1025-1033.

PubMed Abstract | Free Full Text

33. Barp J, Araújo AS, Fernandes TR, et al:: Myocardial antioxidant and oxidative stress changes due to sex hormones. Braz J Med Biol Res. 2002; 35(9): 1075-81. PubMed Abstract | Publisher Full Text

34. Ide $\mathrm{T}$, Tsutsui $\mathrm{H}$, Ohashi $\mathrm{N}$, et al:: Greater oxidative stress in healthy young men compared with premenopausal women. Arterioscler Thromb Vasc Biol. 2002 22(3): 438-42.

PubMed Abstract | Publisher Full Text

35. Matarrese $\mathrm{P}$, Colasanti $\mathrm{T}$, Ascione $\mathrm{B}$, et al:: Gender disparity in susceptibility to oxidative stress and apoptosis induced by autoantibodies specific to RLIP76 in vascular cells. Antioxid Redox Signal. 2011; 15(11): 2825-36.

PubMed Abstract | Publisher Full Text

36. Bhatia K, Elmarakby AA, El-Remessey AB, et al:: Oxidative stress contributes to sex differences in angiotensin II-mediated hypertension in spontaneously hypertensive rats. Am J Physiol Regul Integr Comp Physiol. 2012; 302(2): R274-82. PubMed Abstract | Publisher Full Text | Free Full Text

37. Ama Moor VJ, Pieme CA, Chetcha Chemegne B, et al:: Oxidative profile of sickle cell patients in a Cameroonian urban hospital. BMC Clin Pathol. 2016; 16(1): 15. PubMed Abstract | Publisher Full Text | Free Full Text

38. Guaiquil VH, Vera JC, Golde DW: Mechanism of vitamin C inhibition of cell death induced by oxidative stress in glutathione-depleted HL-60 cells. $J$ Biol Chem. 2001; 276(44): 40955-40961. PubMed Abstract | Publisher Full Tex

39. Egini O, Guillaume $\mathrm{E}$, Adeyemo $\mathrm{T}$, et al: Dataset 1 in: In vitro regulation of reactive oxygen species formation in red blood cells of homozygous sickle cell patients using Vitamin C. F1000Research. 2017. Data Source 


\title{
Open Peer Review
}

\section{Current Peer Review Status: ? ?}

\section{Version 1}

Reviewer Report 26 February 2018

https://doi.org/10.5256/f1000research.13124.r30594

(C) 2018 Olayemi E. This is an open access peer review report distributed under the terms of the Creative Commons Attribution License, which permits unrestricted use, distribution, and reproduction in any medium, provided the original work is properly cited.

\section{Edeghonghon Olayemi}

Department of Haematology, College of Health Sciences (CHS), University of Ghana, Accra, Ghana

The authors set out to investigate a possible in vitro role for Vitamin C in reducing Reactive Oxygen Species (ROS) formation in sickle cell disease patients.

\section{Comments}

\begin{abstract}
Were there matched controls? How were they selected?

\section{Introduction}

The study ignored the role of glucose 6 phosphate dehydrogenase status which plays an important role in protecting red cells against oxidative stress; especially since a significant proportion of the population at the study site will be G6PD deficient. G6PD plays an important role in the production and removal of ROS.
\end{abstract}

\section{Methods}

The sample size is rather small, how was this determined? What was the study design?

The inclusion / exclusion criteria did not state if the patients were in steady state or not and if so how was this determined?

The calculation of the baseline ROS prediction score is not clear.

\section{Results}

It is known that obesity is associated with increased ROS generation, thus, addition of data from overweight patients and the 4 patients with 'unknown' BMI to those of patients with normal BMI could have adversely affected the results. These patients should be excluded in calculating the association between BMI and ROS.

The finding that men produced more ROS may be related to their G6PD status. 
Is the work clearly and accurately presented and does it cite the current literature? Partly

Is the study design appropriate and is the work technically sound?

Partly

Are sufficient details of methods and analysis provided to allow replication by others? Yes

If applicable, is the statistical analysis and its interpretation appropriate?

I cannot comment. A qualified statistician is required.

Are all the source data underlying the results available to ensure full reproducibility? Partly

Are the conclusions drawn adequately supported by the results?

No

Competing Interests: No competing interests were disclosed.

Reviewer Expertise: Benign haematology specifically sickle cell disease and coagulation

I confirm that I have read this submission and believe that I have an appropriate level of expertise to confirm that it is of an acceptable scientific standard, however I have significant reservations, as outlined above.

Reviewer Report 29 August 2017

https://doi.org/10.5256/f1000research.13124.r24997

(C) 2017 Fibach E. This is an open access peer review report distributed under the terms of the Creative Commons Attribution License, which permits unrestricted use, distribution, and reproduction in any medium, provided the original work is properly cited.

\section{Eitan Fibach}

Department of Hematology, Hadassah University Hospital, Ein-Kerem, Jerusalem, Israel

The authors measured the in vitro effect of vitamin $C$ on reactive oxygen species generation in RBC of patients with Sickle Cell Disease.

\section{Comments}

The data are not entirely novel. The authors should cite previous studies on the oxidative status of RBC from patients with sickle cell disease and their response to antioxidants, including Vit. C. For example, Amer et al. ${ }^{1}$

The experimental approach is not clear. 
For example:

\section{Abstract}

"matched controls" - here and elsewhere - what does it mean? RBC of SCA patients not treated with Vit C? what about normal individuals?

\section{Materials and reagents}

"Blood transfusion rate" - Provide data. When were the blood samples obtained? Before/after transfusion?

"Cell staining and flow cytometry" - How were the cells analyzed and ROS determined? "number of ROS per ul" - not clear. "per ul" of what? Before or after washing? Why not calculate the ROS per washed RBC?

\section{Relationship between baseline ROS count and patient characteristics}

"Baseline ROS count (BRC) refers to number of ROS per ul before any red cell intervention." What does "before any red cell intervention" mean?

"Baseline ROS prediction score" - Explain "prediction score"

\section{Other comments}

\section{Introduction}

"Paulson et al." - Change to Pauling et al.

"Paulson et al. demonstrated a direct quantitative effect of the sickle gene pair on sufferers2." explain.

“...during the reperfusion state..." - explain.

Table 1. Baseline characteristics of study participants. The parameters should be shown per males and females.

Figure 3. - What does "positive control" mean?

\section{References}

1. Amer J, Ghoti H, Rachmilewitz E, Koren A, et al.: Red blood cells, platelets and polymorphonuclear neutrophils of patients with sickle cell disease exhibit oxidative stress that can be ameliorated by antioxidants.Br J Haematol. 2006; 132 (1): 108-13 PubMed Abstract | Publisher Full Text

Is the work clearly and accurately presented and does it cite the current literature? No

Is the study design appropriate and is the work technically sound? 
Are sufficient details of methods and analysis provided to allow replication by others? No

If applicable, is the statistical analysis and its interpretation appropriate?

I cannot comment. A qualified statistician is required.

Are all the source data underlying the results available to ensure full reproducibility? No

Are the conclusions drawn adequately supported by the results?

Partly

Competing Interests: No competing interests were disclosed.

I confirm that I have read this submission and believe that I have an appropriate level of expertise to confirm that it is of an acceptable scientific standard, however I have significant reservations, as outlined above.

The benefits of publishing with F1000Research:

- Your article is published within days, with no editorial bias

- You can publish traditional articles, null/negative results, case reports, data notes and more

- The peer review process is transparent and collaborative

- Your article is indexed in PubMed after passing peer review

- Dedicated customer support at every stage

For pre-submission enquiries, contact research@f1000.com

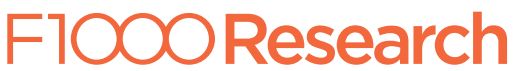

